\title{
Diversity of endophytic phosphate solubilising fungi associated with Pomatocalpa decipiens (Lindl.) J.J. Smith - an endangered orchid in Barbara forest of Odisha, India
}

\section{Sahoo HR and Gupta N*}

Division of Plant Pathology and Microbiology, Regional Plant Resource Centre, Bhubaneswar-751015, Odisha, India.

Sahoo HR, Gupta N 2018 - Diversity of endophytic phosphate solubilising fungi associated with Pomatocalpa decipiens (Lindl.) J.J. Smith - an endangered orchid in Barbara forest of Odisha, India. Studies in Fungi 3(1), 84-99, Doi 10.5943/sif/3/1/11

\begin{abstract}
Investigations were done to obtain potential phosphate solubilising strains from endophytic mycoflora isolated from the orchid, Pomatocalpa decipiens. 928 endophytic phosphate solubilising fungal isolates were obtained from 2400 leaf segments ( $0.38 \%$ recovery) from rare epiphytic orchid Pomatocalpa decipiens present in the Barbara hills of Odisha (India). A number of isolates belonged to different genera such as Paecilomyces, Curvularia, Aspergillus, Cladosporium, Penicillium, Colletotrichum, while others, which were unidentified were classified as mycelia sterilia. Root sampling done from 25 different sites resulted in isolation of 20 endophytic phosphate solubilising fungal isolates from 300 segments (0.1\% recovery). Aspergillus, Paecilomyces, Fusarium, Penicillium, and mycelia sterilia were mostly obtained. The qualitative and quantitative assessments of Phosphate (P) solubilisation were performed using TCP and Rock phosphate as $\mathrm{P}$ source for those strains. Aspergillus niger (leaf isolate) showed a maximum of 33.2 and $22.7 \%$ solubilisation in presence of TCP and Rock phosphate respectively whereas Aspergillus niger (Root isolate) showed a maximum of about $23.9 \%$ and $36.2 \%$ solubilisation in presence of TCP and Rock phosphate respectively.
\end{abstract}

Key words - Fungal endophytes - Phosphate solubilisation - Rock phosphate - Tricalcium Phosphate

\section{Introduction}

Orchidaceae family comprises about 779 genera and 22,500 species and is known to be the second largest family of flowering plants in the world (Mabberley 2008). India is also rich in orchid flora having 1331 species, however the number of endangered orchids is 404 (39.6\% of endangered orchids) out of 1,331 total number of orchids (Misra 2007).Eastern Ghats which forms a broken chain of hill ranges extends through the states of Odisha, Andhra Pradesh and Tamil Nadu (Jalal \& Jayanthi 2012) is considered to have an incredible diversity of orchids containing about 150 species of which 131 have been reported from state of Odisha. Orchids can be classified into 3 groupsholomycotrophic or saprophytic (grows on dead and decaying matter), terrestrials (grows on ground) and epiphytic (grows on trees or shrubs) based on their varying habits (Ma et al 2015). Pomatocalpa decipiens (Lindl.) J.J. Smith is an endangered epiphytic orchid which is found in India and confined to Barbara hills located at Khurdha district of Odisha at a range of 550 metres 
above the sea level and the orchid has been reported from Barbara forest of Odisha only (Panda \& Patnaik 1986).

Fungi are key components of tropical ecosystems and diversified as per habitats and hosttypes (e.g. Jeewon et al. 2003, Kodsueb et al. 2006, Selvi \& Balagangadhara Thilagar 2014). The largest diversity has been reported to present in tropical and subtropical rain forests ecosystems (e.g. Tang et al. 2005, Vijaykrishna et al. 2005, Pinnoi et al. 2007, Banerjee 2011). However, endophytic fungi have also been identified from plant species present in different biomes such as tundra, dry deserts, marine substrata, tropical rainforests etc. (e.g. Liu et al. 2010, Jeewon et al. 2013, 2017, Doilom et al. 2017). They are found in almost all plants including liverworts, hornworts, mosses, lycophytes, equisetopsids, ferns and seed plants (Bacon \& White 2000). Moreover, a number of factors such as geography, environment, as well as age and specific plant tissues are also linked to endophytic biodiversity (Gange et al. 2007, Selosse \& Schardl 2007).

Microbial interaction with orchids and their role in plant growth and development initiated with germination, seedling growth and establishment are very well reported (Dias et al. 2009, Smith \& Read 1997). The mycorrhizal dependency of several orchids make fungal flora of orchids very important on which several research groups are concentrating for the conservation of rare and threatened orchids in India and worldwide (Roy et al. 2009). Though mycorrhizal fungi are symbiotically important for the survival of epiphytic orchids (Ramsay \& Dixon 2003), other endophytic microbiota associated with orchids has also opened an avenue for search of many bioactive products (Dreyfuss \& Chapela 1994, Strobel \& Daisy 2003, Tomita 2003, Urairuj et al 2003, Wildman 2003) useful for agriculture, forestry and health care industry. Several reports in recent years have documented studies on endophytic fungi from orchids (Bayman et al. 2002, Otero et al. 2002). Occurrence of endophytic fungi has been reported in several endemic, endangered and threatened orchids of India and abroad (Chen et al. 2013a, Oliveira et al. 2014).

It is fact that Phosphorus is vital nutrient for agricultural sustenance which is present in deficit quantity in most of the soil types of the world and the deficiency can be ruled out by substitution of phosphate solubilising microbes like bacteria and fungi (Scervino et al. 2011) Studies on endophytic fungal potential for $\mathrm{P}$ solubilisation in vitro as well as in vivo are scarce. Few reports are available on the fungal flora of orchids analysed for mineral solubilising properties (Yang et al. 2014).Till date, no report on either fungal endophyte communities or their phosphate solubilising potential associated with Pomatocalpa decipiens orchid is available. In view, a study has been planned to analyse the diversity of phosphate solubilising fungal population from Pomatocalpa decipiens - an endangered orchid in Odisha, India.

\section{Materials \& Methods}

\section{Collection sites and plant materials}

Barbara forests are located between 19 degree 41' and 20 degree 26' North latitude and 84 degree 59' and 85 degree 56' East longitude. The annual rainfall is 60-70 mm. Leaf and root samples of orchid Pomatocalpa decipiens attached to different host plants are collected from 25 different sites of Barbara forest Division, Khurdha district, Odisha, India were collected and brought to the laboratory in an ice box and used to isolate phosphate solubilising fungi of endophytic nature within 72 hours of collection.

\section{Selective isolation of endophytic fungi}

Healthy and intact plant parts such as leaf and root were packed and carefully transported to laboratory within $24 \mathrm{~h}$. The sample plants were treated by following the protocol for sterilization to remove the dirt and microorganism present on the plant surface. Various parts of the plant which include leaf, root etc. were washed thoroughly under tap water to remove dirt and then with distilled water. The samples were then surface sterilized in the following sequence first treated with $90 \%$ ethanol for $1 \mathrm{~min}$, then $0.5 \%$ Sodium hypochlorite for 5 minutes followed by $90 \%$ ethanol for $1 \mathrm{~min}$ and finally washed with distilled water for 2 times (Bayman et al. 1997). The root and leaf 
were cut into thin sections about $3-4 \mathrm{~mm}$ and inoculated into Pikovskaya's medium and selective isolation of phosphate solubilising organisms was carried out in duplicates. The plates were incubated in dark at $28^{\circ} \mathrm{C}$ for 6-7 days. Halozone forming fungi were selected, isolated and purified for further study.

\section{Identification of endophytic fungi}

The fungi were identified mainly based on morphological characteristics observed through plate culture and slide culture technique and identified with the aid of taxonomic keys (Mehrotra \& Aneja 1990, Mehrotra 1992, Nagamani et al. 2006).

\section{Measurement of fungal occurrence}

It was established by calculating the colonisation frequency, isolation frequency, colonisation rates and isolation rates. The density of colonisation was calculated as the percentage of segments infected by fungal isolates from the total number of segments of each tissue plated following the method of Petrini \& Fisher (1988). Colonization rate (CR) was determined as the total number of plant tissue segments where fungal infection occurred divided by the total number of segments incubated. Isolation rate (IR) was calculated as the total number of fungal isolates obtained from plant segments divided by the total number of plant segments incubated. Colonization frequency (CF) was calculated as the number of plant segments colonized by a single endophyte divided by the total number of segments observed $\times 100$. Isolation frequency (IF) was calculated as the total number of fungal isolates belonging to one species divided by the total number of fungal isolates in that sample $\times 100$.

\section{Species diversity indices}

Species diversity is calculated in terms of species richness and evenness. The Gleason index $\left(\mathrm{H}_{\mathrm{G}}\right)$ is sensitive to richness aspects of diversity and the Shannon index $\left(\mathrm{H}_{\mathrm{S}}\right)$ includes both richness and evenness aspects (Groth \& Roelfs 1987). Relative indices were calculated for Gleason $\left(\mathrm{H}_{\mathrm{GR}}\right)$ and Shannon $\left(\mathrm{H}_{\mathrm{SR}}\right)$ to evaluate the ratio of species richness over the evenness in order to display the extent of species richness of the fungal community. The Simpson index is regarded as a measure of dominance (Simpson 1949).

\section{Screening of the isolates for Phosphate solubilization}

Endophytic fungal isolates were inoculated to Pikovskaya's agar medium and incubated at $28^{\circ} \mathrm{C}$ for 5-7 days. Solubilization efficiency (SE) was calculated (Gaur 1990) and Solubilization index (S.I.) was measured using the formula (Edi-Premono et al. 1996)

S.E $(\%$ P SOLUBILIZATION $)=$ Halozone diameter/Colony diameter X 100

S.I. $=$ Colony diameter + halo zone diameter/colony diameter

\section{Quantitative estimation of tri calcium and rock phosphate solubilisation} (Vanadophosphomolybdate method, Jackson 1958)

The fungi was inoculated into Pikovskaya's broth medium in triplicates and incubated at $28^{\circ} \mathrm{C}$ for 10 days. Mycelium was separated from culture broth after 10 days of incubation. Initial $\mathrm{pH}$ and change in $\mathrm{pH}$ was noted for all the samples with the help of digital $\mathrm{pH}$ meter followed by analysis of $\mathrm{P}$ in broth. $10 \mathrm{ml}$ of sample was centrifuged at $1500 \mathrm{rpm} / 15 \mathrm{~min} .5 \mathrm{ml}$ sample was mixed with $10 \mathrm{ml}$ reagent and made up to $50 \mathrm{ml}$ with distilled water. The above mixture was incubated for 30 minutes at room temperature. Then O.D. was taken at $420 \mathrm{~nm}$, concentration of phosphate was calculated from standard graph. The amount of soluble $\mathrm{P}$ was calculated from standard curve of $\mathrm{KH}_{2} \mathrm{PO}_{4}$. Absorbance of the developing yellow colour was measured at $420 \mathrm{~nm}$ wave length with UV- VIS spectrophotometer (Specord 50). 


\section{Results}

The surface sterilisation treatment of plant tissues (leaf/root) collected from different sites (Figs 1, 2, Table 1) was done. Specific Pikovsakaya's medium was used for isolation of endophytic phosphate solubilising fungi. The fungi exhibiting phosphate solubilising potential were segregated on record of halozone formation around the growing colony. The occurrence of such fungi from leaves has been depicted in Fig. 3. Together with Mycelia sterilia, Paecilomyces, Curvularia, Aspergillus, Cladosporium, Colletotrichum, Penicillium and were the key genera among the 928 fungal isolates obtained from 2400 leaf segments (0.38\% recovery). Paecilomyces lilacinus and Colletotrichum crassipes were recorded from 18 and 16 different sites, respectively. From 300 segments of roots of Pomatocalpa decipiens, a total of 20 endophytic fungal isolates having phosphate solubilising were recovered (0.1\% recovery) representing Aspergillus, Paecilomyces, Fusarium, Penicillium and Mycelia sterilia as shown in Fig. 4.

The site wise variation of fungal endophytes was studied in leaf and root segments as shown in Figs 5, 6. Paecilomyces lilacinus was the dominant fungi which was isolated from leaf samples in 18 sites among the representative fungal taxa (76\% dominance). In case of root mycoendophytes, Penicillium oxalicum was obtained from 4 different sites (16\% dominance). However, most of the root endophytes were recovered only from a single site and their distribution is restricted in that site. Paecilomyces lilacinus and Penicillium oxalicum were the dominant fungi spread over a maximum number of sites.

The Isolation Rate (IR) and Colonization Rate (CR) of fungal isolates from leaf indicated that site 4 has highest IR and CR of 0.99 and 0.8 , respectively. The lowest value of IR and CR 0.03 was seen in site 17. When observed with root isolates, the values obtained for IR and CR are equal. Sites 5 and 24 have high IR and CR values of 0.25 . Nevertheless, the overall IR and CR of P solubiliser from leaf is 0.39 and 0.37 respectively whereas that of root is low about 0.07 as depicted in Table 2. Hence, more number of endophytes was associated with leaf samples as compared to root. Data obtained on isolation and colonization frequency of fungal species in leaf and root samples of Pomatocalpa decipiens are presented at Table 3. However, there is recovery of mostly common species in case of root fungi as depicted in Table 4.

The number of species present and their relative abundance (species richness and diversity) is represented in Table 5. Gleason index $\left(\mathrm{H}_{\mathrm{G}}\right)$ for leaf and root community showed lower value as it ranges from 2-4 which suggests that there is lesser species richness. Shannon-Weiner index $\left(\mathrm{H}_{\mathrm{S}}\right)$ ranged from 1.5-3.5 which shows species evenness. Similarly as $\mathrm{H}_{\mathrm{SR}}>\mathrm{H}_{\mathrm{GR}}$ there is more species evenness in the community than that of species richness. However more Pielou's evenness is observed in root isolates as compared to leaf isolates as $0.82>0.3$. The dominance index (D) in root is higher than leaf $(10>6.49)$ suggests that most of the species have higher number of isolates in leaf.

The $\mathrm{P}$ solubilisation potential in solid medium by fungi obtained from leaf was recorded in Table 6. Solubilization index ranged from 1.2-1.94 in all fungal isolates and it was higher in Penicillium verruculosum and Curvularia lunata (1.94), Aspergillus niger (1.87). The fungi were further tested for their solubilisation capacity in broth medium using TCP as P-source. 13 fungi showed a decrease in $\mathrm{pH}$ of the medium whereas there is rise in $\mathrm{pH}$ as compared to control in case of 4 fungi as shown in Table 6. Here, Aspergillus niger and Cladosporium herbareum showed maximum decrease in $\mathrm{pH}$ in the range of 4-4.5 and they showed highest solubilisation of $33.2 \%$ and $34.9 \%$ respectively. Both the isolates were further tested for the capacity to solubilize rock phosphate in broth medium where Aspergillus niger showed higher solubilisation potential as compared to Cladosporium herbareum as shown in Table 7.

The fungi from root of the plant were also screened for solubilisation in solid pikovskaya's medium and their solubilisation index ranged from 1.19-1.65 which is comparatively lower than the fungi obtained from leaf. Penicillium oxalicum showed higher solubilisation index as compared to other fungi (Table 8). They were also screened for their ability of solubilising $\mathrm{P}$ in broth medium. The maximum decrease in $\mathrm{pH}$ was recorded in Aspergillus fumigatus but higher $\mathrm{P}$ solubilisation was observed in two different species of Aspergillus followed by Penicillium. Aspergillus niger and 
Aspergillus fumigatus showed $23.9 \%$ and $19.2 \% \mathrm{P}$ solubilisation, respectively whereas Penicillium oxalicum and Penicillium glabrum showed solubilisation percentage of $17.6 \%$ and $17.1 \%$, respectively (Table 8). All these 4 fungi were further tested for their rock phosphate solubilising capacity, although there is no decrease in the $\mathrm{pH}$ of the medium as compared to control but Aspergillus niger showed $36.2 \%$ rock phosphate solubilisation and Penicillium oxalicum showed $25 \%$ solubilisation (Table 9).

\section{Discussion}

There are several reports on endophytic fungi from tropical orchids such as Paeciliomyces species from Vanda, Colletotrichum species from Lepanthes and Dendrobium and Fusarium frequently obtained from different orchids such as Satyrium nepalense and Dendrobium nobile (Bayman et al. 1997, Chen et al. 2013b, Jyothsna \& Purushothama 2014, Yuan et al. 2009). However, there is no data on the diversity of fungal endophytic communities associated with Pomatocalpa decipiens. The endophytic flora of the present study can be compared with the orchids from other regions of tropical or temperate nature. The endophytic composition of Pomatocalpa decipiens consisted of many general and cosmopolitan species like Aspergillus, Cladosporium, Curvularia, Fusarium, Paecilomyces and Penicillium. Endophytic fungi such as Aspergillus, Trichoderma and Verticillium have also been repeatedly found in orchids (Kasmir et al. 2011). Non-mycorrhizal fungi related to Chytridiomycota (i.e. Olpidium), Glomeromycota and Zygomycota (i.e. Umbelopsis) have also been reported in Orchids which is higher than the different fungal taxa obtained for Pomatocalpa decipiens from our study (Roy et al. 2009, Zhao et al. 2014).

Table 1 GPS reading of sampling sites

\begin{tabular}{|c|c|c|}
\hline Site no. & Site of location & GPS reading \\
\hline 1 & CHULIJINKA SIDEWAY & $19^{0} 51^{\prime} .038 \mathrm{~N}, 85^{\circ} 01^{\prime} .042 \mathrm{E}$ \\
\hline 2 & GIRIPOOJA & $19^{0} 53^{\prime} .038 \mathrm{~N}, 85^{\circ} 03^{\prime} .214 \mathrm{E}$ \\
\hline 3 & GIRIPOOJA & $19^{0} 53^{\prime} .379 \mathrm{~N}, 85^{\circ} 03^{\prime} .189 \mathrm{E}$ \\
\hline 4 & TAMANA-10 & $19^{0} 53^{\prime} .379 \mathrm{~N}, 85^{\circ} 03^{\prime} .189 \mathrm{E}$ \\
\hline 5 & TAMANA-10 & $19^{0} 53^{\prime} .379 \mathrm{~N}, 85^{\circ} 03^{\prime} .189 \mathrm{E}$ \\
\hline 6 & TAMANA-10 & $19^{0} 53^{\prime} .370 \mathrm{~N}, 85^{\circ} 03^{\prime} .166 \mathrm{E}$ \\
\hline 7 & GIRIPOOJA & $19^{0} 53^{\prime} .038 \mathrm{~N}, 85^{\circ} 03^{\prime} .214 \mathrm{E}$ \\
\hline 8 & GIRIPOOJA & $19^{0} 53^{\prime} .038 \mathrm{~N}, 85^{\circ} 03^{\prime} .214 \mathrm{E}$ \\
\hline 9 & TAMANA-10 & $19^{0} 53^{\prime} .382 \mathrm{~N}, 85^{\circ} 03^{\prime} .206 \mathrm{E}$ \\
\hline 10 & TAMANA-10 & $19^{0} 53^{\prime} .382 \mathrm{~N}, 85^{\circ} 03^{\prime} .206 \mathrm{E}$ \\
\hline 11 & TAMANA-10 & $19^{0} 53^{\prime} .361 \mathrm{~N}, 85^{\circ} 03^{\prime} .202 \mathrm{E}$ \\
\hline 12 & TAMANA-10 & $19^{0} 53^{\prime} .361 \mathrm{~N}, 85^{\circ} 03^{\prime} .202 \mathrm{E}$ \\
\hline 13 & TAMANA-10 & $19^{0} 53^{\prime} .361 \mathrm{~N}, 85^{\circ} 03^{\prime} .202 \mathrm{E}$ \\
\hline 14 & TAMANA-10 & $19^{0} 53^{\prime} .364 \mathrm{~N}, 85^{\circ} 03^{\prime} .154 \mathrm{E}$ \\
\hline 15 & TAMANA-10 & $19^{0} 53^{\prime} .364 \mathrm{~N}, 85^{\circ} 03^{\prime} .154 \mathrm{E}$ \\
\hline 16 & RAJIN RESERVE FOREST & $19^{0} 52^{\prime} .197 \mathrm{~N}, 85^{\circ} 02^{\prime} .180 \mathrm{E}$ \\
\hline 17 & RAJIN RESERVE FOREST & $19^{0} 52^{\prime} .197 \mathrm{~N}, 85^{\circ} 02^{\prime} .180 \mathrm{E}$ \\
\hline 18 & TOWARDS MAHULIA & $19^{0} 52^{\prime} .330 \mathrm{~N}, 85^{\circ} 01^{\prime} .587 \mathrm{E}$ \\
\hline 19 & TOWARDS MAHULIA & $19^{0} 52^{\prime} .321 \mathrm{~N}, 85^{\circ} 01^{\prime} .547 \mathrm{E}$ \\
\hline 20 & TOWARDS MAHULIA & $19^{0} 52^{\prime} .321 \mathrm{~N}, 85^{\circ} 01^{\prime} .547 \mathrm{E}$ \\
\hline 21 & TOWARDS MAHULIA & $19^{0} 52^{\prime} .325 \mathrm{~N}, 85^{\circ} 01^{\prime} .460 \mathrm{E}$ \\
\hline 22 & TOWARDS MAHULIA & $19^{0} 52^{\prime} .325 \mathrm{~N}, 85^{\circ} 01^{\prime} .460 \mathrm{E}$ \\
\hline 23 & TOWARDS MAHULIA & $19^{0} 52^{\prime} .325 \mathrm{~N}, 85^{\circ} 01^{\prime} .460 \mathrm{E}$ \\
\hline 24 & TOWARDS MAHULIA & $19^{0} 52^{\prime} .356 \mathrm{~N}, 85^{\circ} 01^{\prime} .435 \mathrm{E}$ \\
\hline 25 & TOWARDS MAHULIA & $19^{0} 52^{\prime} .356 \mathrm{~N}, 85^{\circ} 01^{\prime} .435 \mathrm{E}$ \\
\hline
\end{tabular}




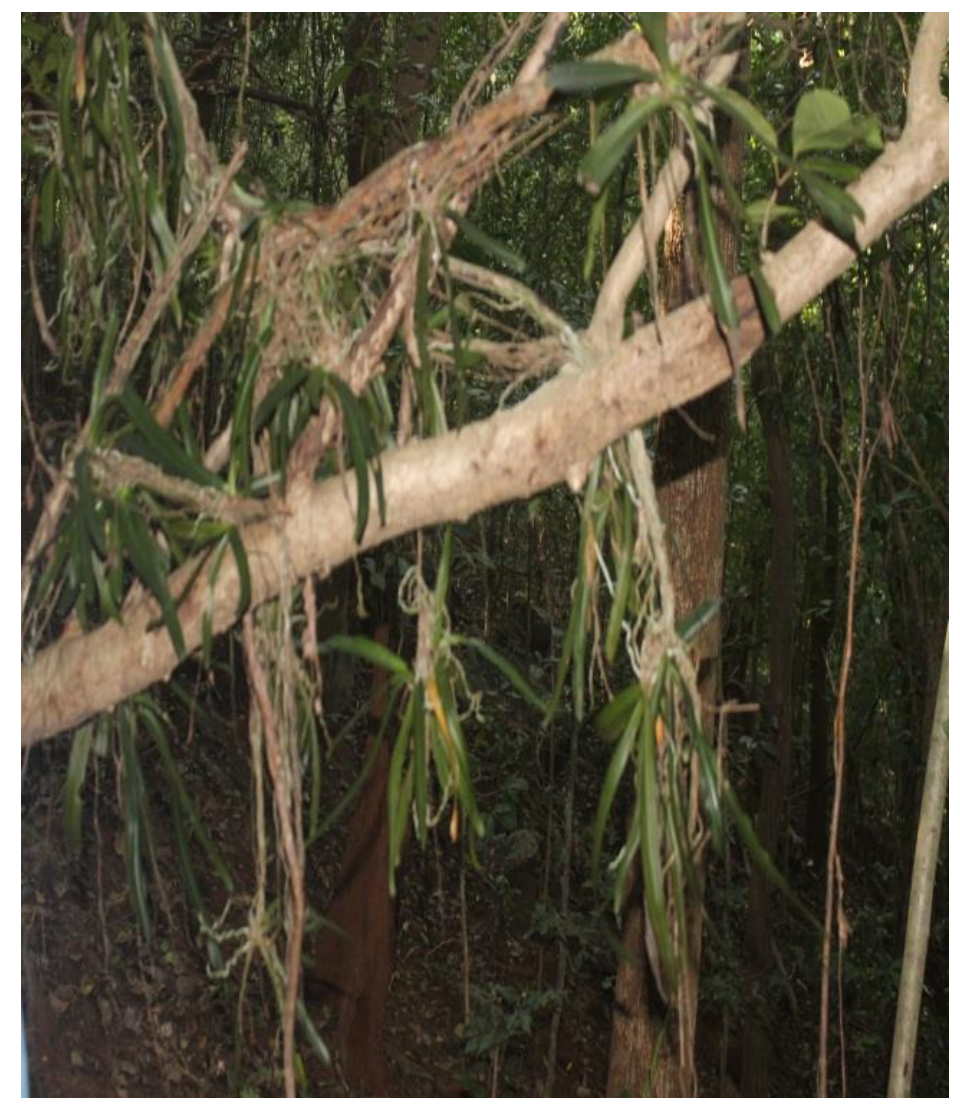

Fig. 1 - Field photograph showing Orchid Pomatocalpa decipiens attached to host plant in Barbara forest

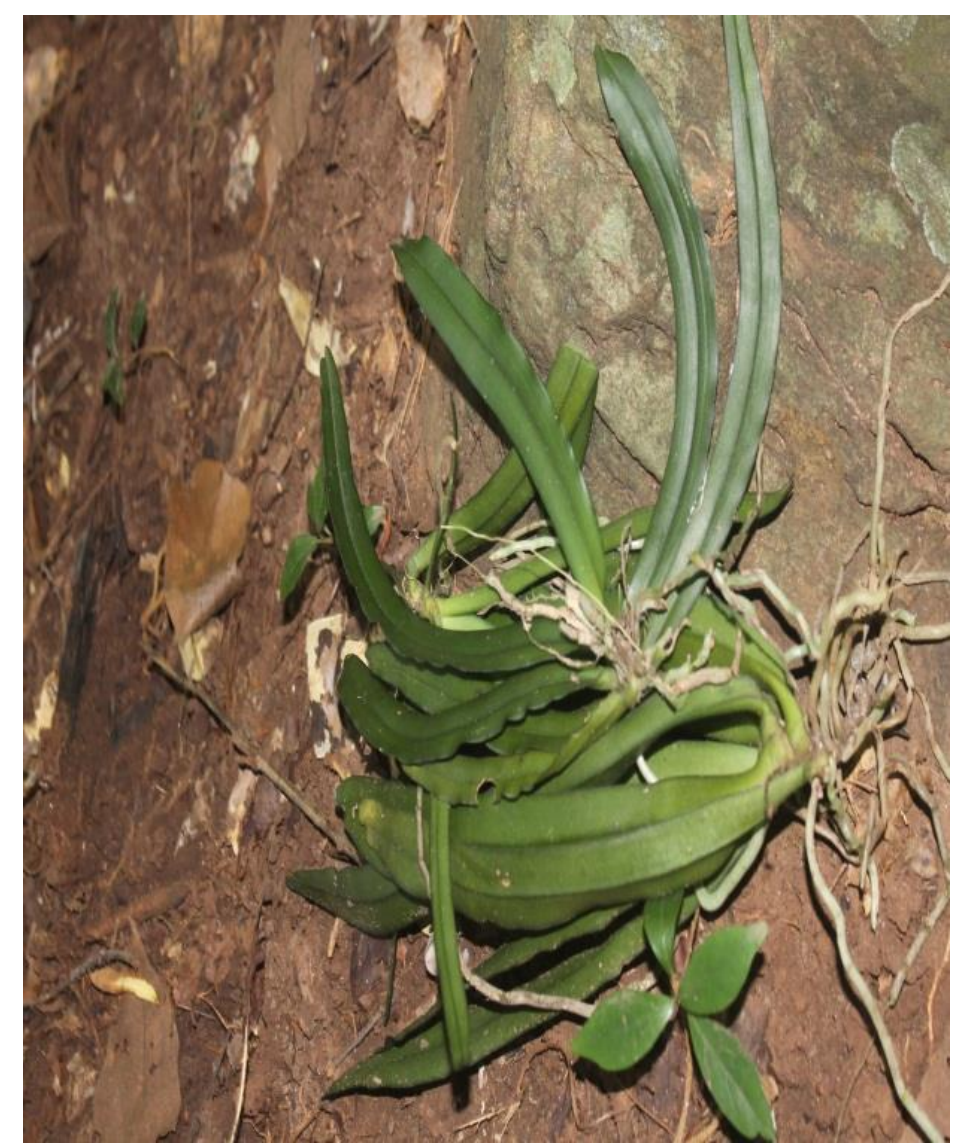

Fig. 2 - Leaf and root part of Pomatocalpa decipiens Orchid 


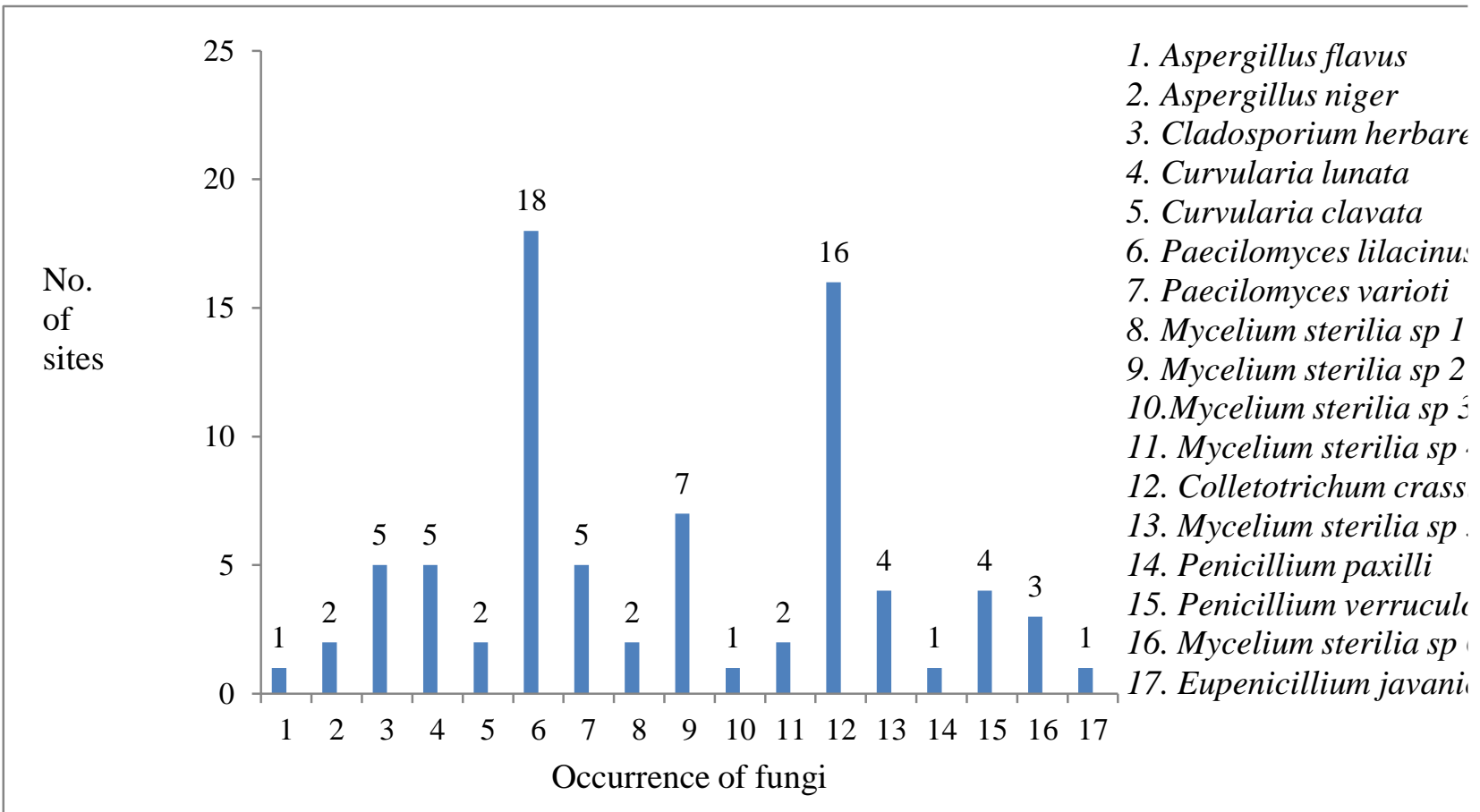

Fig. 3 - Occurrence of Phosphate solubilising fungi in leaves of Pomatocalpa decipiens

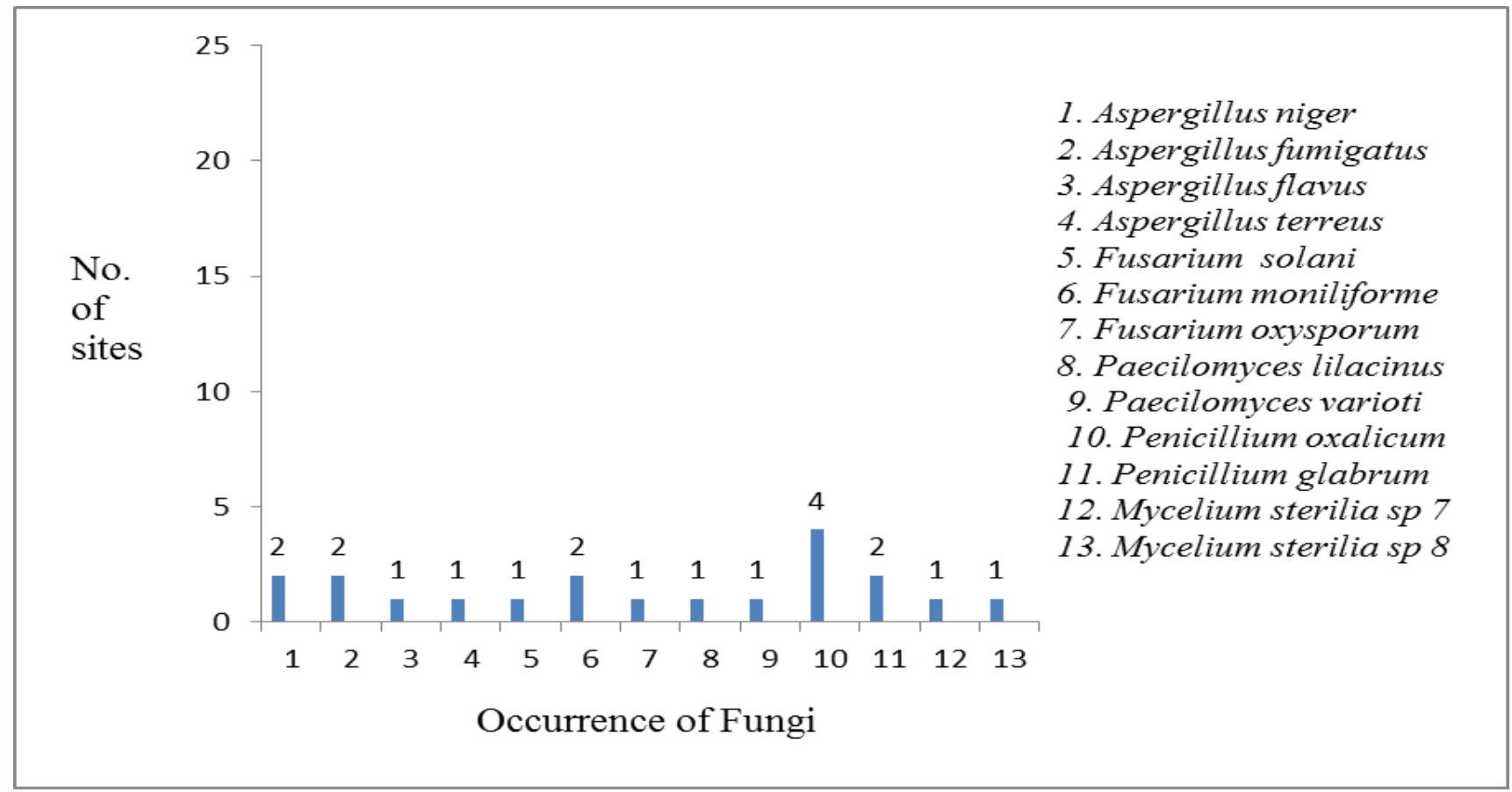

Fig. 4 - Occurrence of Phosphate solubilising fungi from roots of Pomatocalpa decipiens in 25 different sampling sites of Barbara forest 


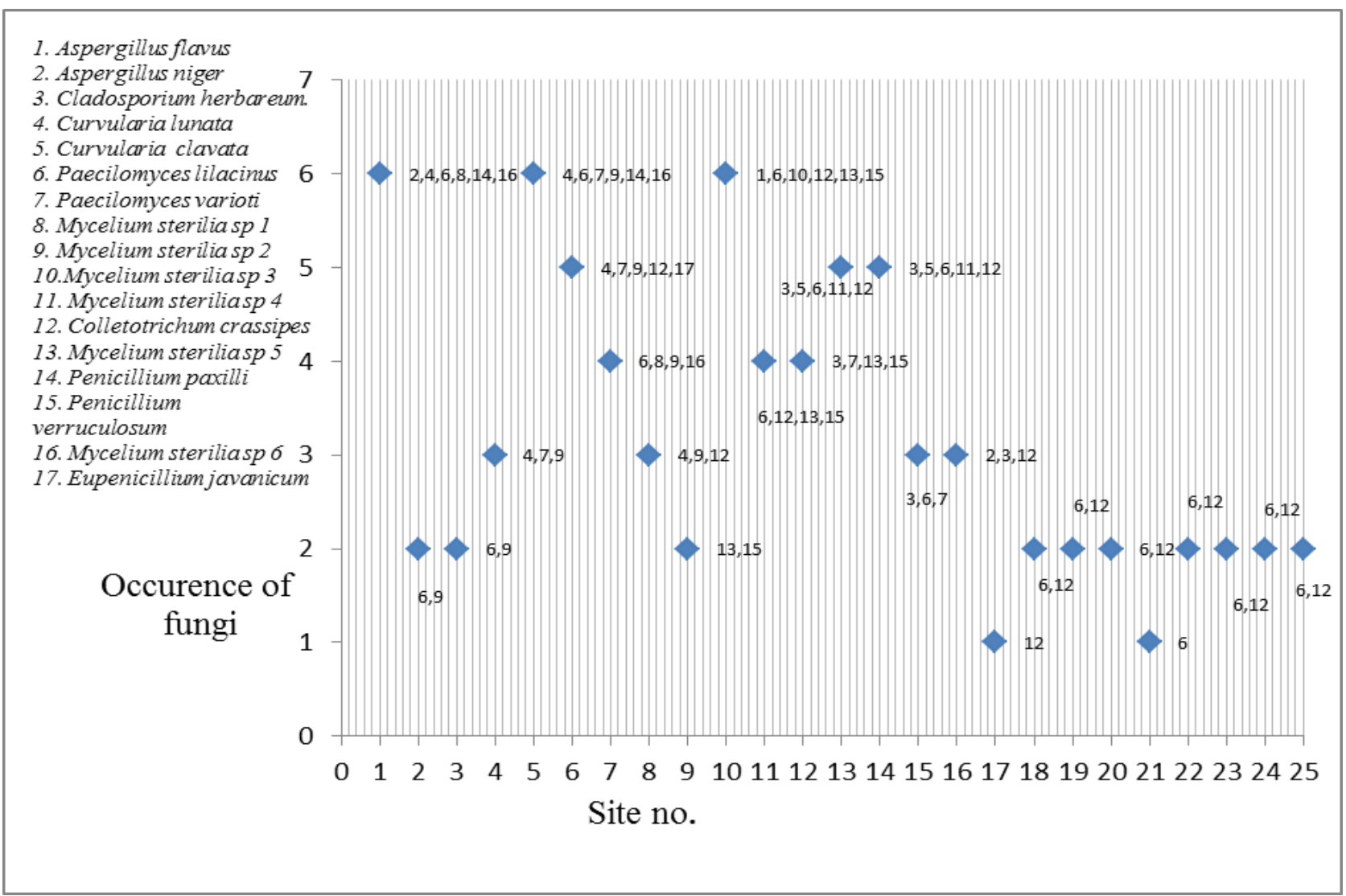

Fig. 5 - Occurrence of no. of $\mathrm{P}$ solubilising fungal taxa isolated from leaf of Pomatocalpa decipiens in 25 different sites

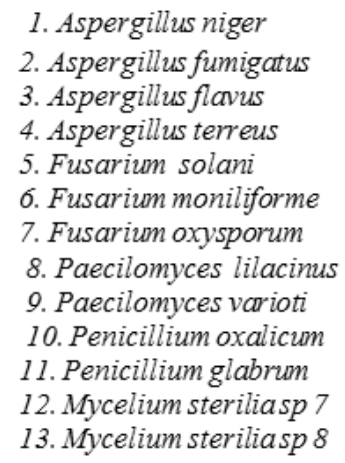

1. Aspergillus niger

2. Aspergillus fumigatus

3. Aspergillus flavus

4. Aspergillus terreus

5. Fusarium solani

6. Fusarium moniliforme

7. Fusarium oxysporum

8. Paecilomyces lilacinus

9. Paecilomyces varioti

10. Penicillium oxalicum

11. Penicillium glabrum

12. Mycelium steriliasp 7

13. Mycelium steriliasp 8

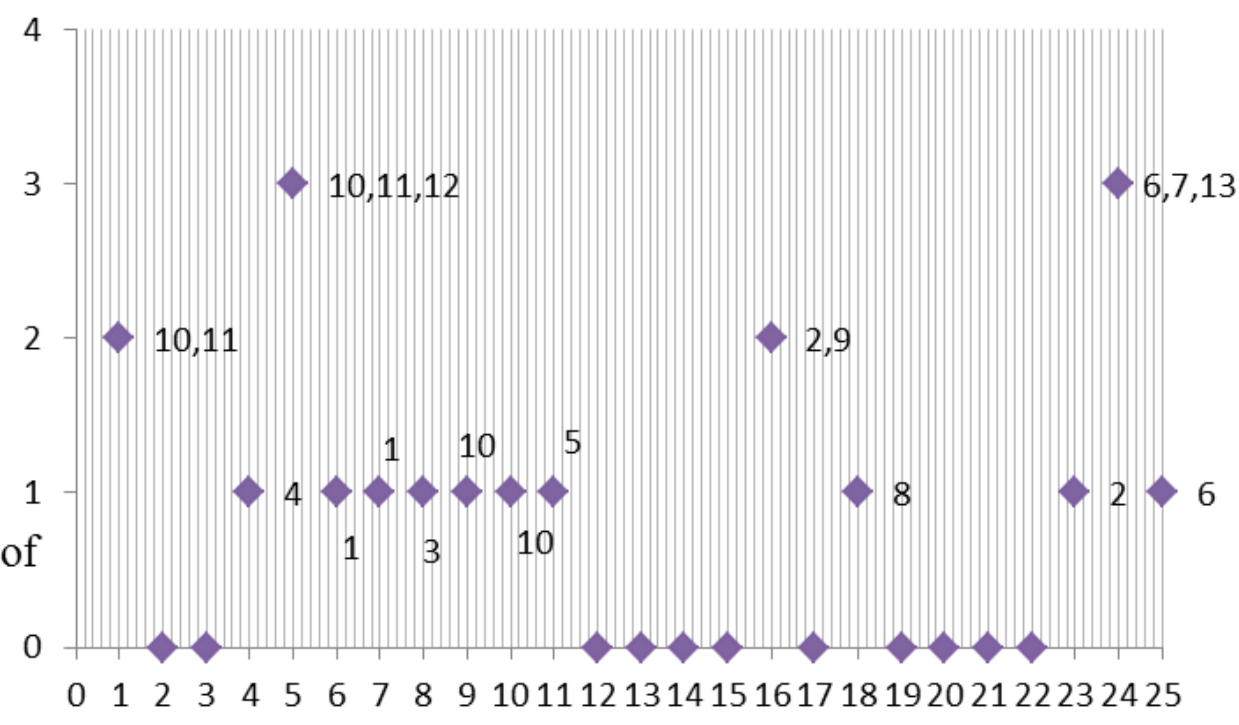

Site no.

Fig. 6 - Occurrence of no. of $\mathrm{P}$ solubilising fungal taxa isolated from Root of Pomatocalpa decipiens in 25 different sites 
Table 2 Isolation Rate (IR) and Colonization Rate (CR) of P solubilising fungal isolates from leaf and root sample

\begin{tabular}{|c|c|c|c|c|}
\hline & LEAF & & ROOT & \\
\hline SITE & $\begin{array}{c}\text { ISOLATION } \\
\text { RATE }\end{array}$ & $\begin{array}{c}\text { COLONIZATION } \\
\text { RATE }\end{array}$ & $\begin{array}{c}\text { ISOLATION } \\
\text { RATE }\end{array}$ & $\begin{array}{c}\text { COLONIZATION } \\
\text { RATE }\end{array}$ \\
\hline S1 & 0.61 & 0.56 & 0.17 & 0.17 \\
\hline S2 & 0.69 & 0.68 & 0 & 0 \\
\hline S3 & 0.54 & 0.54 & 0 & 0 \\
\hline S4 & 0.99 & 0.8 & 0.08 & 0.08 \\
\hline S5 & 0.31 & 0.31 & 0.25 & 0.25 \\
\hline S6 & 0.3 & 0.28 & 0.08 & 0.08 \\
\hline S7 & 0.67 & 0.63 & 0.08 & 0.08 \\
\hline S8 & 0.19 & 0.19 & 0.08 & 0.08 \\
\hline S9 & 0.51 & 0.51 & 0.08 & 0.08 \\
\hline S10 & 0.41 & 0.4 & 0.08 & 0.08 \\
\hline S11 & 0.22 & 0.21 & 0.08 & 0.08 \\
\hline S12 & 0.3 & 0.3 & 0 & 0 \\
\hline S13 & 0.65 & 0.65 & 0 & 0 \\
\hline S14 & 0.63 & 0.63 & 0 & 0 \\
\hline S15 & 0.54 & 0.54 & 0 & 0 \\
\hline S16 & 0.34 & 0.35 & 0.17 & 0.17 \\
\hline S17 & 0.03 & 0.03 & 0 & 0 \\
\hline S18 & 0.04 & 0.04 & 0.08 & 0.08 \\
\hline S19 & 0.45 & 0.43 & 0 & 0 \\
\hline S20 & 0.15 & 0.15 & 0 & 0 \\
\hline S21 & 0.06 & 0.06 & 0 & 0 \\
\hline S22 & 0.04 & 0.04 & 0 & 0 \\
\hline S23 & 0.375 & 0.375 & 0.08 & 0.08 \\
\hline S24 & 0.36 & 0.36 & 0.25 & 0.25 \\
\hline S25 & 0.25 & 0.25 & 0.08 & 0.08 \\
\hline TOTAL & 0.39 & 0.37 & 0.07 & 0.07 \\
\hline
\end{tabular}

Table 3 Isolation Frequency (IF) and Colonization Frequency (CF) of $17 \mathrm{P}$ solubilising Fungal isolates from leaf sample

\begin{tabular}{cccc}
\hline SI No. & Name of organism & $\begin{array}{c}\text { ISOLATION } \\
\text { FREQUENCY }\end{array}$ & $\begin{array}{c}\text { COLONIZATION } \\
\text { FREQUENCY }\end{array}$ \\
\hline 1 & Aspergillus flavus & $0.11 \%$ & $0.04 \%$ \\
2 & Aspergillus niger & $0.65 \%$ & $0.25 \%$ \\
3 & Cladosporium herbareum & $17.90 \%$ & $6.90 \%$ \\
4 & Curvularia lunata & $9.60 \%$ & $3.70 \%$ \\
5 & Curvularia clavata & $0.54 \%$ & $0.21 \%$ \\
6 & Paecilomyces lilacinus & $25.22 \%$ & $9.75 \%$ \\
7 & Paecilomyces varioti & $3.34 \%$ & $1.29 \%$ \\
8 & Mycelium sterilia sp 1 & $0.43 \%$ & $0.17 \%$ \\
9 & Mycelium sterilia sp 2 & $16.30 \%$ & $6.29 \%$ \\
10 & Mycelium sterilia sp 3 & $0.11 \%$ & $0.04 \%$ \\
\hline
\end{tabular}


Table 3 Continued.

\begin{tabular}{cccc}
\hline SI No. & Name of organism & $\begin{array}{c}\text { ISOLATION } \\
\text { FREQUENCY }\end{array}$ & $\begin{array}{c}\text { COLONIZATION } \\
\text { FREQUENCY }\end{array}$ \\
\hline 11 & Mycelium sterilia sp 4 & $0.22 \%$ & $0.08 \%$ \\
12 & Colletotrichum crassipes & $12.50 \%$ & $4.83 \%$ \\
13 & Mycelium sterilia sp 5 & $6.14 \%$ & $2.38 \%$ \\
14 & Penicillium paxilli & $0.11 \%$ & $0.04 \%$ \\
15 & Penicillium verruculosum & $5.50 \%$ & $2.13 \%$ \\
16 & Mycelium sterilia sp 6 & $1.30 \%$ & $0.50 \%$ \\
17 & Eupenicillium javanicum & $0.11 \%$ & $0.04 \%$ \\
\hline
\end{tabular}

Table 4 Isolation Frequency (IF) and Colonization Frequency (CF) of $13 \mathrm{P}$ solubilising Fungal isolates from root sample

\begin{tabular}{cccc}
\hline SI No. & Name of organism & $\begin{array}{c}\text { ISOLATION } \\
\text { FREQUENCY }\end{array}$ & $\begin{array}{c}\text { COLONIZATION } \\
\text { FREQUENCY }\end{array}$ \\
\hline 1 & Aspergillus niger & $10 \%$ & $0.70 \%$ \\
2 & Aspergillus fumigatus & $10 \%$ & $0.70 \%$ \\
3 & Aspergillus flavus & $5 \%$ & $0.30 \%$ \\
4 & Aspergillus terreus & $5 \%$ & $0.30 \%$ \\
5 & Fusarium solani & $5 \%$ & $0.30 \%$ \\
6 & Fusarium moniliforme & $10 \%$ & $0.70 \%$ \\
7 & Fusarium oxysporum & $5 \%$ & $0.30 \%$ \\
8 & Paecilomyces lilacinus & $5 \%$ & $0.30 \%$ \\
9 & Paecilomyces varioti & $5 \%$ & $0.30 \%$ \\
10 & Penicillium oxalicum & $20 \%$ & $1.30 \%$ \\
11 & Penicillium glabrum & $10 \%$ & $0.70 \%$ \\
12 & Mycelium sterilia sp 7 & $5 \%$ & $0.30 \%$ \\
13 & Mycelium sterilia sp 8 & $5 \%$ & $0.30 \%$ \\
\hline
\end{tabular}

Table 5 Species diversity indices of leaf and root samples

\begin{tabular}{ccccccccc}
\hline & TISSUE FUNGAL & & & & & & \\
SL NO. & COMMUNITY & Ni & Np & HG & HS & HSR(J) & HGR & D \\
\hline 1 & LEAF & 928 & 17 & 2.34 & 2.04 & 0.3 & 0.02 & 6.49 \\
2 & ROOT & 20 & 13 & 4.01 & 2.44 & 0.82 & 0.63 & 10 \\
\hline
\end{tabular}

$\mathrm{Ni}=$ total number of fungal isolates, $\mathrm{Np}=$ number of fungal groups, $\mathrm{HG}=$ Gleason index, $\mathrm{HS}=$ Shannon-weiner index, $\mathrm{J}=$ Relative index for Shannon index $\left(\mathrm{H}_{\mathrm{SR}}\right)$ or Pielou's evenness, HGR= Relative index for Gleason index, $\mathrm{D}=\mathrm{Simpson}$ dominance index

Table 6 Determination of phosphate solubilisation in fungi isolated from leaf of orchid Pomatocalpa decipiens using TCP as P-source

\begin{tabular}{cccc}
\hline Fungi & $\begin{array}{c}\text { pH of culture } \\
\text { filtrate } \\
\text { (in broth) }\end{array}$ & $\begin{array}{c}\text { \% P } \\
\text { SOLUBILISED } \\
\text { (in liquid broth) }\end{array}$ & $\begin{array}{c}\text { Solubilisation Index } \\
\text { (in solid medium) }\end{array}$ \\
\hline Aspergillus flavus & $6.413 \pm 0.214$ & $4 \pm 0.53$ & 1.2 \\
Aspergillus niger & $4.376 \pm 0.099$ & $33.2 \pm 1.23$ & 1.875 \\
Cladosporium & $4.503 \pm 0.234$ & $34.9 \pm 0.92$ & 1.21 \\
herbareum & & & \\
\hline
\end{tabular}


Table 6 Continued.

\begin{tabular}{cccc}
\hline Fungi & $\begin{array}{c}\text { pH of culture } \\
\text { filtrate } \\
\text { (in broth) }\end{array}$ & $\begin{array}{c}\text { \% P } \\
\text { SOLUBILISED } \\
\text { (in liquid broth) }\end{array}$ & $\begin{array}{c}\text { Solubilisation Index } \\
\text { (in solid medium) }\end{array}$ \\
\hline Curvularia lunata & $7.18 \pm 0.136$ & $3.47 \pm 0.9$ & 1.94 \\
Curvularia clavata & $8.63 \pm 0.226$ & $2.2 \pm 1.49$ & 1.31 \\
Paecilomyces lilacinus & $6.52 \pm 0.272$ & $1.5 \pm 0.46$ & 1.43 \\
Paecilomyces varioti & $6.963 \pm 0.06$ & $2.1 \pm 0$ & 1.57 \\
Mycelium sterilia sp 1 & $6.06 \pm 0.098$ & $8.5 \pm 1.9$ & 1.25 \\
Mycelium sterilia sp 2 & $6.52 \pm 0.100$ & $3.8 \pm 0.74$ & 1.51 \\
Mycelium sterilia sp 3 & $5.45 \pm 0.444$ & $4.6 \pm 0.21$ & 1.4 \\
Mycelium sterilia sp 4 & $8.57 \pm 0.243$ & $3.3 \pm 0.8$ & 1.57 \\
Colletotrichum crassipes & $5.653 \pm 0.212$ & $4.3 \pm 0.81$ & 1.31 \\
Mycelium sterilia sp 5 & $5.88 \pm 0.356$ & $2.3 \pm 0.82$ & 1.2 \\
Penicillium paxilli & $5.073 \pm 0.265$ & $8.6 \pm 4.21$ & 1.37 \\
Penicillium & $5.5 \pm 0.052$ & $4.6 \pm 1.96$ & 1.94 \\
verruculosum & $5.63 \pm 0.382$ & $7 \pm 2.8$ & 1.4 \\
Mycelium sterilia sp 6 & $7.78 \pm 1.536$ & $2.8 \pm 1.97$ & 1.36 \\
Eupenicillium javanicum & & & \\
\hline
\end{tabular}

Table 7 Determination of phosphate solubilisation in selected fungi isolated from leaf of orchid Pomatocalpa decipiens using RP as P-source

\begin{tabular}{lcc}
\hline Fungi & $\begin{array}{l}\text { pH of culture filtrate } \\
\text { (in broth) }\end{array}$ & $\begin{array}{l}\text { \% P } \\
\text { SOLUBILISED } \\
\text { (in liquid broth) }\end{array}$ \\
\hline $\begin{array}{l}\text { Aspergillus niger } \\
\begin{array}{l}\text { Cladosporium } \\
\text { herbareum }\end{array}\end{array}$ & $5.03 \pm 0$ & $22.7 \pm 0.46$ \\
\hline
\end{tabular}

Table 8 Determination of phosphate solubilisation in fungi isolated from root of orchid Pomatocalpa decipiens using TCP as P-source

\begin{tabular}{lccc}
\hline Fungi & $\begin{array}{l}\text { pH of culture filtrate } \\
\text { (in broth) }\end{array}$ & $\begin{array}{l}\text { \% P } \\
\text { SOLUBILISED } \\
\text { (in liquid broth) }\end{array}$ & $\begin{array}{c}\text { Solubilisation Index } \\
\text { (in solid medium) }\end{array}$ \\
\hline Aspergillus niger & $5.94 \pm 0.05$ & $23.9 \pm 2.27$ & 1.5 \\
Aspergillus fumigatus & $4.84 \pm 0.12$ & $19.2 \pm 0.46$ & 1.31 \\
Aspergillus flavus & $7.47 \pm 0.09$ & $11.9 \pm 2.65$ & 1.19 \\
Aspergillus terreus & $6.68 \pm 0.03$ & $5.6 \pm 1.23$ & 1.35 \\
Fusarium solani & $6.79 \pm 0.15$ & $3.6 \pm 0.06$ & 1.21 \\
Fusarium moniliforme & $8.73 \pm 0.14$ & $1.9 \pm 0.39$ & 1.19 \\
Fusarium oxysporum & $6.34 \pm 0.02$ & $3.8 \pm 0.31$ & - \\
Paecilomyces lilacinus & $8.66 \pm 0.08$ & $1.9 \pm 0$ & 1.6 \\
Paecilomyces varioti & $8.81 \pm 0.05$ & $1.6 \pm 0.14$ & 1.33 \\
Penicillium oxalicum & $5.84 \pm 0.10$ & $17.6 \pm 4.1$ & 1.65 \\
Penicillium glabrum & $5.44 \pm 0.11$ & $17.1 \pm 2.21$ & 1.32 \\
\hline
\end{tabular}


Table 8 Continued.

\begin{tabular}{lccc}
\hline Fungi & $\begin{array}{l}\text { pH of culture filtrate } \\
\text { (in broth) }\end{array}$ & $\begin{array}{l}\text { \% P } \\
\text { SOLUBILISED } \\
\text { (in liquid broth) }\end{array}$ & $\begin{array}{l}\text { Solubilisation Index } \\
\text { (in solid medium) }\end{array}$ \\
Mycelium sterilia sp 7 & $6.14 \pm 0.13$ & $7.8 \pm 0.21$ & 1.19 \\
Mycelium sterilia sp 8 & $6.67 \pm 0.05$ & $6.9 \pm 0.23$ & - \\
\hline
\end{tabular}

Table 9 Determination of phosphate solubilisation in selected fungi isolated from root of orchid Pomatocalpa decipiens using RP as P-source.

\begin{tabular}{lcc}
\hline Fungi & $\begin{array}{l}\text { pH of culture filtrate } \\
\text { (in broth) }\end{array}$ & $\begin{array}{l}\text { \% P } \\
\text { SOLUBILISED } \\
\text { (in liquid broth) }\end{array}$ \\
\hline Aspergillus niger & $7.45 \pm 0.04$ & $36.2 \pm 5.6$ \\
Aspergillus fumigatus & $8.25 \pm 0.06$ & $12.7 \pm 2.8$ \\
Penicillium oxalicum & $8.05 \pm 0.10$ & $25 \pm 4$ \\
Penicillium glabrum & $7.83 \pm 0.07$ & $15.7 \pm 1.25$ \\
\hline
\end{tabular}

Isolation and colonization rates of endophytic mycoflora in various tissues of $P$. decipiens were found in the order: root<leaf. Studies by Sudheep \& Sridhar 2012 also reveal that there is less microfloral association in epiphytic roots.

The endophytic association of different plant tissues like leaf and root showed that few fungi were common in roots and leaf tissues like Aspergillus and Paecilomyces. The root tissues of Pomatocalpa decipiens harboured 4 species of Aspergillus, 3 species of Fusarium other than Penicillium and Paecilomyces. Several studies have demonstrated that fungal colonization by Fusarium is common in roots of orchid (Sowmya et al. 2013). Many sterile mycelia were isolated from leaf and root samples tested for Pomatocalpa decipiens. The sterile forms have often been isolated from many orchids (Rajgopal \& Suryanarayana 2000). In the present study, 6 sterile mycelium in leaf and 2 in root have been isolated. Analysis of fungal species composition and colonization densities in Pomatocalpa decipiens are well specified by presence of several endophytic fungal populations. The species composition and frequency is dependent upon tissue types (Kumar \& Hyde 2004). It is very interesting to note that the mycotrophic colonization rate in leaf of Pomatocalpa decipiens is higher as compared to root. This is in line with Petrini et al. (1992) who stated that the plant organ harbours distinct microhabitat with reference to endophyte infections. In the present study, Simpson's dominance index (D) in leaf (6.49) is lower than the root (10). The Shannon index values in leaf and root are more or less similar which confirms the species evenness.

Phosphate Solubilising Micro-organisms render insoluble phosphate into soluble form through processes such as acidification, chelation, and exchange reactions in the soil environment Vassilev \& Vassileva 2003) through secretion of organic acids which is mediated through lowering of $\mathrm{pH}$. It has been confirmed in the present study as Cladosporium herbareum and Aspergillus niger reduces the $\mathrm{pH}$ to $4.503 \pm 0.234$ and $(4.376 \pm 0.099)$ respectively. Aspergillus fumigatus from roots of Pomatocalpa decipiens has also resulted into lowering of $\mathrm{pH}$ of culture broth. The organic acid production by these organisms also imparted on the $\% \mathrm{P}$ solubilisation in solid and liquid culture state. These organisms are useful alternative in order to meet the phosphate deficiency where high input of phosphatic fertilizer is required. It is also important to note that these fungi in association with Pomatocalpa decipiens are able to solubilize rock phosphate also, although they do not change the $\mathrm{pH}$ very much, indicating lower level extracellular production of organic acid into the medium (Table 9). However, Aspergillus niger showed good $\mathrm{P}$ solubilising activity i.e. $22.7 \pm 0.46$ and $36.2 \pm 5.6$ isolated from leaf and root. The fungal genera with efficient phosphate 
solubilization ability include Aspergillus, Candida, Discosia, Eupenicillium, Gliocladium, Mucor, Penicillium, Trichoderma, Yeast, Aspergillus and Penicillum (Xiao et al. 2008, Rahi et al. 2009). The process of $\mathrm{P}$ solubilization of Phosphate Solubilising Fungi depends not only on the insoluble inorganic phosphate source, type of carbon, nitrogen and metal ions in soil, but also on culture conditions (Nahas 2007, Jain et al. 2012).

\section{Conclusion}

It is very important to note that the source plants are endangered in India only found in Odisha. Occurrence of $\mathrm{P}$ solubilising fungal population from endangered sources having good $\mathrm{P}$ solubilising activity can serve as a good option for isolation and screening of potent $\mathrm{P}$ solubilising organisms (Sahoo et al. 2014). Present study paves the way to conserve the rare fungi from the endangered plants. However, more emphasis has been given to conserve the RET orchids of India. Though in the present study a partial picture of endophytic assemblages of Pomatocalpa decipiens have been traced out. Further elaborative work on seasonal variation and specificity of endophytic microflora, diversity and analysis of exploitable potential will provide us with a clear sketch regarding the endemism and rarity in distribution of Pomatocalpa decipiens in the field.

\section{Acknowledgements}

The financial assistance obtained (in part) through Forest and Environment Department, Govt. of Odisha (State Plan Project) and INSPIRE programme, (No. DST/INSPIRE Fellowship/2013/506) DST, Govt. of India is gratefully acknowledged. The logistic support for Field visit and sampling of materials is also acknowledged to Division forest office of Khurdha district, Odisha. Authors are thankful to Dr. P. C. Panda, Principal Scientist, Plant Taxonomy \& Conservation Division, RPRC and his technical field staff for identification of Plant material.

\section{References}

Bacon CW, White JF. 2000 - Physiological adaptations in the evolution of endophytism in the Clavicipitaceae. In: S. C. Redlin and L. M. Carris (Eds.) Microbial Endophytes, Marcel Dekker, New York. pp. 237-261.

Banerjee D. 2011 - Endophytic fungal diversity of tropical and subtropical plants. Research Journal of Microbiology 6, 54-62.

Bayman P, Gonza'lez EJ, Fumero JJ, Tremblay RL. 2002 - Are fungi necessary? How fungicides affect growth and survival of the orchid Lepanthes rupestris in the field. Journal of Ecology 90, 1002-1008.

Bayman P, Lebron LL, Tremblay RL, Lodge DJ. 1997 - Variation in endophytic fungi from roots and leaves of Lepenthes (orchidaceae). New phytologist 135,143-49.

Chen XH, Guan JJ, Ding R, Zhang Q, Ling XZ. 2013a - Conservation genetics of the endangered terrestrial orchid Liparis japonica in Northeast China based on AFLP markers. Plant Systematics and Evolution 299, 691-698.

Chen J, Zhang LC, Xing YM, Wang YQ, Xing XK. 2013b - Diversity and taxonomy of endophytic Xylariaceous fungi from medicinal plants of Dendrobium (Orchidaceae). PLOS ONE 8, e58268.

Dias ACF, Costa FEC, Andreote FD, Lacava PT et al. 2009 - Isolation of micropropagated strawberry endophytic bacteria and assessment of their potential for plant growth promotion. World Journal of Microbiology and Biotechnology 25,189-195.

Doilom M, Manawasinghe IS, Jeewon R, Jayawardena RS et al. 2017 - Can ITS sequence data identify fungal endophytes from cultures? A case study from Rhizophora apiculata. Mycosphere 8, 1869-1892.

Dreyfuss MM, Chapela IH. 1994 - Potential of fungi in discovery of novel low molecular weight pharmaceuticals. In: The discovery of Natural Products with Therapeutic Potential (ed. V.P. Gullo). Butterworth-Heinemann, London, UK. Pp 49-80 
Edi-Premono M, Moawad MA, Vleck PLG. 1996 - Effect of phosphate solubilizing Pseudmonas putida on the growth of maize and its survival in the rhizosphere. Indonasian Journal of Crop Science 11, 13-23.

Gange AC, Dey S, Currie AF, Sutton BVC. 2007 - Site and species-species differences in endophyte occurrence in two herbaceous plants. Journal of Ecology 95, 614-22.

Gaur A, Rana J, Jalali B, Chand H. 1990 - Role of VA mycorrhizae, phosphate solubilizing bacteria and their interactions on growth and up-take of nutrients by wheat crops. In: The National Conference on Mycorrhizae (1990: Hisar, India) .Proceeding. Hisar, India: Trends in Mycorrhizal Research. Pp 105-106.

Groth JV, Roelfs AP. 1987 - The concept of measurement of phenotypic diversity in Puccinia graminis on wheat. Phytopathology 77, 1394-1399.

Jackson ML. 1958 - Soil Chemical Analysis. Prentice Hall Inc. Englowoodcliff, NewJersey, USA.

Jain R, Saxena J, Sharma V. 2012 - Solubilization of inorganic phosphates by Aspergillus awamori S19 isolated from agricultural soil of semi-arid region. Annals of Microbiology 62, 725-735.

Jalal JS, Jayanthi J. 2012 - Endemic orchids of peninsular India: a review. Journal of Threatened Taxa 4(15), 3415-3425.

Jeewon R, Cai L, Zhang K, Hyde KD. 2003 - Dyrithiopsis lakefuxianensis gen et sp. nov. from Fuxian Lake, Yunnan, China and notes on the taxonomic confusion surrounding Dyrithium. Mycologia 95, 911-920.

Jeewon R, Ittoo J, Mahadeb D, Jaufeerally-Fakim Y et al. 2013 - DNA based identification and phylogenetic characterisation of endophytic and saprobic fungi from Antidesma madagascariense, a medicinal plant in Mauritius. Journal of Mycology (http://www.hindawi.com/journals/mycology/aip/781914/)

Jeewon R, Wanasinghe DN, Rampadaruth S, Puchooa D et al. 2017 - Nomenclatural and identification pitfalls of endophytic mycota based on DNA sequence analyses of ribosomal and protein genes phylogenetic markers: A taxonomic dead end? Mycosphere 8(10), 18021817, Doi 10.5943/mycosphere/8/10/7

Jyothsna BS, Purushothama KB. 2014 - Psathyrella candolleana (fr.) marie, a saprophytic fungus forming orchid mycorrhiza in Satyrium nepalense d. don from India. Canadian Journal of Pure and Applied Sciences 8(1), 2691-2697.

Kasmir J, Senthilkumar SR, Britto SJL, Raj JM. 2011 - Identification of fungal endophytes from Orchidaceae members based on nrITS (internal transcribed spacer) region. International Research Journal of Biotechnology 2(6), 139-144.

Kodsueb R, Vijaykrishna D, Aptroot A, Lumyong S et al. 2006 - The family Pleosporaceae: intergeneric relationships and phylogenetic perspectives based on sequence analyses of partial 28S rDNA. Mycologia 98: 571-583.

Kumar DSS, Hyde KD. 2004 - Biodiversity and tissue-recurrence of endophytic fungi in Tripterygium wilfordii. Fungal Diversity 17, 69-90.

Liu AR, Chen SC, Lin XM, Wu SY et al. 2010 - Endophytic Pestalotiopsis species associated with plants of Palmae, Rhizophoraceae, Planchonellae and Podocarpaceae in Hainan, China. African Journal of Microbiology Research, 4 (24): 2661-2669.

Ma X, Kang J, Nontachaiyapoom S, Wen T, Hyde KD. 2015 - Non-mycorrhizal endophytic fungi from orchids. Current science 108, 1-16.

Mabberley DJ. 2008 - Mabberley's plant-book: a portable dictionary of plants, their classification and uses, third edition, revised, Cambridge University Press, Cambridge, xviii, 1021pp.

Mehrotra BS. 1992 - The fungi- An introduction. (3rd Edition).Today and Tomorrow Printers and publishers. New Delhi.

Mehrotra RS, Aneja KR. 1990 - An introduction to mycology, Wiley eastern limited, New Delhi.

Misra S. 2007 - Orchids of India - A Glimpse. Bishen Singh Mahendra Pal Singh, Dehradun, pp 402.

Nagamani A, Kunwar IK, Manoharachary C. 2006 - Handbook of Soil Fungi. IK International Pvt ltd. New Delhi. 
Nahas E. 2007 - Phosphate solubilizing microorganisms: Effect of carbon, nitrogen, and phosphorus sources. In: E. Velázquez (ed) First International Meeting on Microbial Phosphate Solubilization, 16-19 July 2002, Salamanca, Spain. pp. 111-115.

Oliveira SF, Bocayuva MF, Veloso TGR, Bazzolli DMS et al. 2014 - Endophytic and mycorrhizal fungi associated with roots of endangered native orchids from the Atlantic Forest, Brazil. Mycorrhiza 24, 55-64.

Otero TJ, Ackerman JD, Bayman P. 2002 - Diversity and host specificity of endophytic Rhizoctonia-like fungi from tropical orchids. American Journal of Botany 89, 1852-1858.

Panda PC, Patnaik SN. 1986 - Pomatocalpa decipiens (Lindl.) Bl. (Orchidaceae) - A new record for India. Journal of Economic and Taxonomic Botany 8(2), 475-476.

Petrini O, Fisher PJ. 1988 - A comparative study of fungal endophytes in xylem and whole stems of Pinus sylvestris and Fagus sylvatica. Transactions of the British Mycological Society 91, 233-238.

Petrini O, Sieber TN, Toti L, Viret O. 1992 - Ecology, metabolite production and substrate utilization in endophytic fungi. Natural Toxins 1, 185-196.

Pinnoi A, Jeewon R, Sakayaroj J, Hyde KD et al. 2007 - Berkleasmium crunisia sp. nov. and its teleomorphic affinities to the Pleosporales based on 18S, 28S and ITS-5.8S rDNA sequence analyses. Mycologia. 99:378-384

Rahi P, Vyas P, Sharma S, Gulati A. 2009 - Plant growth promoting potential of the fungus Discosia sp. FIHB571 from tea rhizosphere tested on chickpea, maize and pea. Indian Journal of Microbiology 49,128-133.

Rajgopal K, Suryanarayanan TS. 2000 - Isolation of endophytic fungi from leaves of neem (Azadirachta indica A. Juss). Current Science 78, 1375-1378.

Ramsay MM, Dixon KW. 2003 - Propagation science, recovery and translocation of terrestrial orchids, pp. 259-288. In: Dixon KW, Kell SP, Barrett RL, Cribb PJ. (eds.). Orchid conservation. Natural History Publications, (Borneo) Kota Kinabalu, Sabah.

Roy M, Watthana S, Stier A, Richard F et al. 2009 - Two mycoheterotrophic orchids from Thailand tropical dipterocarpacean forests associate with a broad diversity of ectomycorrhizal fungi. BMC Biology 7(51), Doi: 10.1186/1741-7007-7-51.

Sahoo HR, Sahoo P, Gupta N. 2014 - Extracellular enzymatic potential and antimicrobial activity of endophytic fungal isolates from Operculina turpethum-an endangered medicinal plant. BMR Microbiology 1(1), 1-7.

Scervino JM, Papinutti VL, Godoy MS, Rodriguez JM et al. 2011 - Medium pH, carbon and nitrogen concentrations modulate the phosphate solubilization efficiency of Penicillium purpurogenum through organic acid production. Journal of Applied Microbiology 110, 12151223.

Selosse MA, Schardl CL. 2007 - Fungal endophytes of grass: hybrids rescued by vertical transmission? An evolutionary perspective. New Phytologist 173, 452-58.

Selvi KB, Balagangadhara Thilagar P. 2014 - Isolation and screening of endophytic fungi from medicinal plants of virudhunagar district for antimicrobial activity. International Journal of Science and Nature 5(1), 147-155.

Simpson EH. 1949 - Measurement of diversity. Nature 163, 688.

Smith SE, Read DJ. 1997 - Mycorrhizal symbiosis. Academic Press, Cambridge, UK.

Sowmya K, Vasudevan TG, Murali TS. 2013. Fungal endophytes from two orchid species -pointer towards organ specificity. Czech Mycology 65(1), 89-101.

Strobel GA, Daisy B. 2003 - Bioprospecting for microbial endophyes and their natural products. Microbiology and Molecular Biology Reviews 67,491-502.

Sudheep NM, Sridhar KR. 2012 - Non-mycorrhizal fungal endophytes in two orchids of Kaiga forest (Western Ghats), India. Journal of Forest Research 23(3), 453-460.

Tang AMC, Jeewon R, Hyde KD. 2005 - Succession of microfungal communities on decaying leaves of Castanopsis fissa. Canadian journal of Microbiology 51 (11), 967-974. 
Tomita F. 2003 - Endophytes in Southeast Asia and Japan: their taxonomic diversity and potential applications. Fungal Diversity 14, 187-204.

Urairuj C, Khanongnuch C, Lumyong S. 2003 - Ligninolytic enzymes from tropical endophytic Xylariaceae. Fungal Diversity 13, 209-219.

Vassilev N, Vassileva M. 2003 - Biotechnological solubilization of rock phosphate on media containing agro-industrial wastes. Applied Microbiology and Biotechnology 61(5-6),435440.

Vijaykrishna D, Jeewon R, Hyde KD. 2005 - Fusoidispora aquatica: New freshwater ascomycetes from Hong Kong based on morphology and molecules. Sydowia 57: 267-280

Wildman HG. 2003 - The rise and fall of natural products screening for drug discovery. Fungal Diversity 13, 221-231.

Xiao C, Chi R, Huang X, Zhang W et al. 2008 - Optimization for rock phosphate solubilizing fungi isolated from phosphate mines. Ecological Engineering 33, 187-193.

Yang S, Zhang X, Cao Z, Zhao K et al. 2014 - Growth-promoting Sphingomonas paucimobilis ZJSH1 associated with Dendrobium officinale through phytohormone production and nitrogen fixation. Microbial Biotechnology 7(6), 611-620.

Yuan ZL, Chen YC, Yang Y. 2009 - Diverse non-mycorrhizal fungal endophytes inhabiting an epiphytic, medicinal orchid (Dendrobium nobile): estimation and characterization. Journal of Microbiology and Biotechnology 25, 295-303.

Zhao XL, Yang JZ, Liu S, Chen CL et al. 2014 - The colonization patterns of different fungi on roots of Cymbidium hybridum plantlets and their respective inoculation effects on growth and nutrient uptake of orchid plantlets. World Journal of Microbiology and Biotechnology 30, 1993-2003. 